\title{
Free-radical reactions for the stereoselective synthesis of amino acid derivatives
}

\author{
Christopher J. Easton \\ Research School of Chemistry, Australian National University, Canberra, ACT 0200, \\ Australia
}

\begin{abstract}
By exploiting the selective hydrogen atom transfer reactions of glycine residues in small peptides, it is possible to utilise other amino acid residues as chiral auxiliaries in stereoselective synthesis. Alternatively, radical side-chain functionalisation of $\mathrm{N}$-phthaloyl-substituted amino acid derivatives occurs without racemisation. The synthetic utility of the latter procedure is enhanced by the ability to use the phthaloyl group in subsequent reactions to remember the chirality of the amino acids.
\end{abstract}

The proteinogenic $\alpha$-amino acids constitute an important pool of optically active starting materials for asymmetric synthesis. Ionic reactions of these compounds have been extensively exploited but less attention has been given to using free radical chemistry in this area. In part this must be attributed to the tendency for amino acid derivatives to form $\alpha$-carbon-centred radicals (ref. 1), with consequent loss of optical purity. Now it has been recognised that there are several ways to either exploit or avoid formation of these species, in order that radical reactions of amino acid derivatives can be accomplished efficiently and in good yield, with a high degree of regio- and stereo-control.

Hydrogen atom transfer reactions of amino acid derivatives are known to be selective for formation of glycinyl radicals (ref. 2-4). For example, treatment of the valylglycine derivative 1 with $\mathrm{N}$ bromosuccinimide gave only the bromide 2 (ref. 4), presumably through bromine incorporation at the site of hydrogen atom abstraction. Bromoglycine derivatives of this type are suitable for further elaboration, as illustrated in the synthesis of the allylglycine derivative 4 and the $\beta$-nitroamino acid derivatives 3 , through reaction of the bromide 2 with allyltributylstannane (ref. 4-6) and alkyl nitronates (ref. 7), respectively. In these reactions the valine residue in the dipeptide derivative 1 is acting as a chiral auxiliary. Given that either enantiomer of the auxiliary is cheap and readily avaliable, and that the auxiliary can be recovered through product hydrolysis and recycled, the limitation to this approach to the asymmetric synthesis of amino acid derivatives is the modest degree of diastereoselectivity.

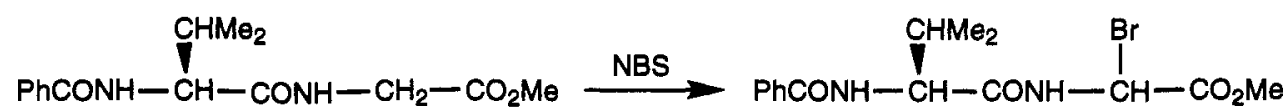

1

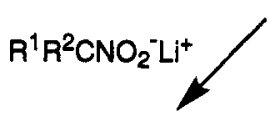

2<smiles>CC=CCCCCCCCCCCC</smiles>

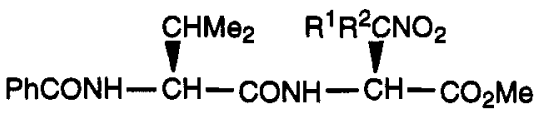

3 d.e. ca. $50 \%$<smiles>C=CC[C@H](NC(=O)[C@H](C)Nc1ccccc1)C(=O)O[Na]</smiles> 
<smiles>CON1CC(=O)N(C(C)C)[C@@H](C)C1=O</smiles>

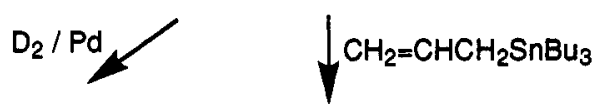<smiles>CON1C(=O)[C@H](C)N(C(C)=O)C(=O)[C@H]1O</smiles>

7 d.e. ca. $95 \%$<smiles>C=CC[C@H]1C(=O)N(C(C)=O)[C@@H](C)C(=O)N1OC</smiles>

8

This limitation may be overcome through the use of more highly constrained systems, in which the relative geometry of the chiral and prochiral centres is more rigidly defined (ref. 8). Accordingly, bromination of the glycine residue in the cyclic dipeptide derivative 5 gave the bromide 6 . Reaction of the bromide 6 with allyltributylstannane gave only the diastereomer 8 , from incorporation of the allyl group anti to the side chain of the valine residue. Deuteriolysis of the bromide 6 gave the labelled product 7 and this reaction also occurred with a high degree of diastereoselectivity. The reactions of the diketopiperazine 5 illustrate an approach for the asymmetric synthesis of amino acid derivatives which is complementary to the Schöllkopf procedure for the elaboration of bislactim ethers (ref. 9).<smiles>[R]OC(=O)[C@@H](Nc1ccccc1)C(C)(C)C</smiles>

9<smiles>[R]C(C)(C)C[C@H](Nc1ccccc1)C(C)=O</smiles>

10<smiles>[2H]C(=O)[C@@H](NPc1ccccc1)c1ccccc1</smiles>

11<smiles>[2H]C(=O)[C@H](NP)[C@H]([2H])c1ccccc1</smiles>

12 a) $\mathrm{R}=\mathrm{H}$

b) $\mathrm{A}=\mathrm{Br}$

a) $\mathrm{R}=\mathrm{OMe}$

b) $\mathrm{R}=\mathrm{NH}-\mathrm{t}-\mathrm{Bu}$<smiles>O=C(O)[C@H](Cc1ccccc1)Nc1ccccc1</smiles>

13

a) $\mathrm{R}=\mathrm{OMe}$

b) $R=\mathrm{NH}-\mathrm{t}-\mathrm{Bu}$<smiles>O=C(O)[C@H](Nc1ccccc1)[C@H](Br)c1ccccc1</smiles>

15<smiles>CCCCCCCC</smiles><smiles>CCCNC(C=Cc1ccccc1)=C(O)c1ccccc1</smiles> 
An alternative way to exploit radical reactions in asymmetric synthesis is to use optically active amino acid derivatives as starting materials, and to carry out reactions on the amino acid side chains, while avoiding formation of the $\alpha$-carbon-centred radicals. This can be accomplished through the use of $N$-phthaloylprotected amino acid derivatives (ref. 10). The amino acid derivatives $9 \mathbf{a}$ and $10 \mathbf{a}$ reacted with $N$. bromosuccinimide, without racemisation, to give the bromides $9 \mathrm{~b}$ and $10 \mathrm{~b}$, respectively. In the case of the phenylalanine derivatives 13a,b, $1: 1$ mixtures of the corresponding bromides $14 \mathbf{a}, \mathbf{b}$ and $15 \mathbf{a}, \mathbf{b}$ were obtained. The diastereomeric pairs were separated by chromatography and fractional crystallisation, and in this way each of the bromides $14 a, b$ and $15 a, b$ was obtained as a single stereoisomer.<smiles>O=C(O)[C@H](O)[C@@H](O)c1ccccc1</smiles>

18<smiles>O=C[C@@H](O)[C@@H](O)c1ccccc1</smiles>

19

a) $R=O M e$

b) $\mathrm{R}=\mathrm{NH}-\mathrm{t}-\mathrm{Bu}$

The bromides 14a,b and 15a,b are suitable for elaboration in stereocontrolled syntheses, and they gave the corresponding dehydrophenylalanine derivatives $16 \mathbf{a}, \mathbf{b}$ and $17 \mathbf{a}, \mathbf{b}$ in reactions with potassium fluoride (ref. 11). Their reactions with deuterium over palladium on carbon resulted in the stereospecific production of the deuterides 11a,b and 12a,b, respectively (ref. 12). Treatment of a 1:1 mixture of the bromide diastereomers 14a and 15a with silver nitrate in aqueous acetone afforded a 5:1 mixture of the corresponding alcohols 18a and 19a, while a mixture of the bromoamides $14 \mathrm{~b}$ and $15 \mathrm{~b}$ gave only the hydroxyamide 18b (ref. 13). The stereoconvergent nature of these transformations negates the need for separation of the bromide diastereomers $14 \mathbf{a}, \mathbf{b}$ and $\mathbf{1 5 a} \mathbf{a}, \mathbf{b}$ prior to reaction. The diastereoselectivity of reaction of the bromophenylalaninamides $14 \mathrm{~b}$ and $15 \mathrm{~b}$ was significantly greater than that of the reactions of the corresponding esters $14 \mathbf{a}$ and $15 \mathbf{a}$, as a result of neighbouring group participation by the amido group, to effectively block one face of the intermediate carbocation (Fig. 1).
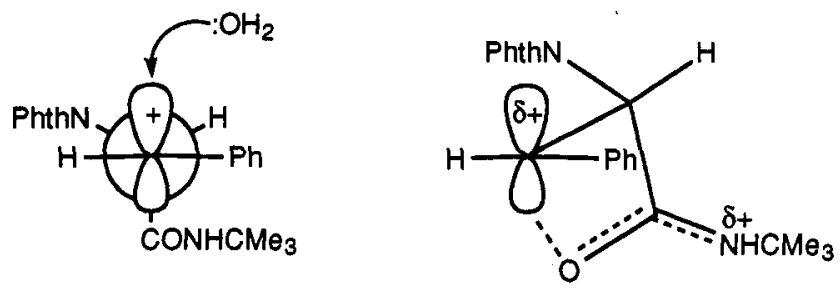

Fig. 1 Neighbouring group participation in reaction of the bromides $14 \mathrm{~b}$ and $15 \mathrm{~b}$

This neighbouring group effect of the carboxyl substituent affects the mechanism of reaction as well as the stereochemical outcome (ref. 14). The nitrophenylalanine derivatives $20 \mathrm{a}$ and $20 \mathrm{~b}$ gave the corresponding bromides $21 \mathrm{a}$ and $21 \mathrm{~b}$, each as a 1:1 mixture of the diastereomers, through reaction with $\mathrm{N}$ bromosuccinimide. On treatment with silver nitrate in aqueous acetone, the bromoester 21a gave the dehydrophenylalanine derivative 22 , while the bromoamide $21 \mathrm{~b}$ afforded the alcohol 23 . Presumably the amide $21 \mathrm{~b}$ reacts by substitution, where formation of the intermediate carbocation is facilitated by the amido group, whereas the ester 21a reacts by elimination because the extent of neighbouring group participation is reduced in that case and, therefore, the corresponding benzylic cation does not form.

Hydrolysis of the alcohol 23 gave the corresponding free amino acid 24, providing a route for the stereocontrolled synthesis of the antibiotic chloramphenicol 25 . In a similar fashion, $(2 S, 3 R)-\beta$-hydroxyphenylalanine and tyrosine were obtained, and these compounds are of interest in the synthesis of peptide antibiotics such as lysobactin and vancomycin. 
<smiles>[R]OC(=O)[C@H](Cc1ccccc1)Nc1ccccc1S</smiles>

20<smiles></smiles>

21

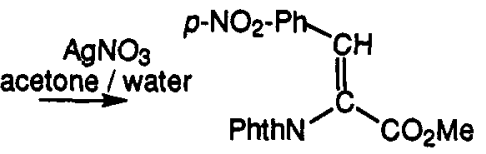

22

a) $\mathrm{R}=\mathrm{OMe}$

b) $\mathrm{R}=\mathrm{NH}-t-\mathrm{Bu}$

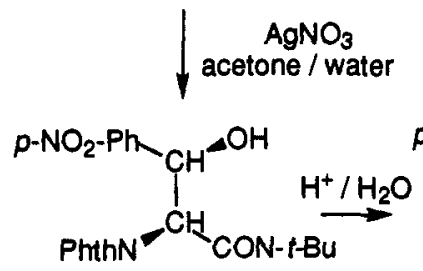

23<smiles>C=CC1CC1</smiles>

24<smiles>CC(=O)N[C@@H](CO)[C@@H](O)[C@H](O)c1ccccc1</smiles>

25

Obviously the phthaloyl protecting group can be removed without racemisation of the amino acid. It is also possible to epimerise the amino acid during the deprotection, by exploiting the phthaloyl group to remember the chirality (ref. 15). The (S)-amino acid derivatives $26 a-c$ reacted with sodium borohydride in methanol, then hydrochloric acid, to give the partially reduced products 27a-c and 28a-c. The diastereomers 27a-c and 28a-c were separated by using either chromatography or fractional crystallisation. Treatment of the $(S, S)$-diastereomers 27a-c with sodium methoxide in methanol resulted in isomerisation at the $\alpha$-position. Again the diastereomers 27a-c and 29a-c were separated and the new components $29 \mathrm{a}-\mathrm{c}$ were hydrolysed to give the $(R)$-amino acids 30a-c, respectively. The $(R, S)$-diastereomers 28a-c were also used to prepare the corresponding $(R)$-amino acids 30a-c, in a similar manner.<smiles>CC(=O)C(P)N1C(=O)c2ccccc2C1=O</smiles>

26

i) $\mathrm{NaBH}_{4} / \mathrm{MeOH}$

ii) $\mathrm{H}^{+}$ a) $R=M e$

b) $\mathrm{R}=\mathrm{CHMe}_{2}$

c) $\mathrm{R}=\mathrm{Ph}$<smiles>[2H][C@@H](OC)N1C(=O)c2ccccc2[C@H]1OC</smiles>

27<smiles>CON(C)C1CCCC1</smiles>

30<smiles>[R]C([C@H](C)OC)N1C(=O)c2ccccc2[C@H]1C(C)C</smiles><smiles>[R]C(C(C)=O)N1C(=O)c2ccccc2[C@H]1OC</smiles>

28<smiles>CC=CN(C)OC</smiles>

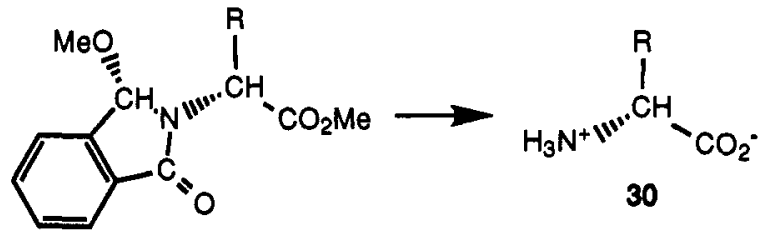


<smiles>[R]C([NH3+])[C@@H](OC)N1C(=O)c2ccccc2[C@H]1OC</smiles>

27 a) $R=\mathrm{Me}$
b) $\mathrm{R}=\mathrm{CHM} \theta_{2}$
c) $\mathrm{R}=\mathrm{Ph}$ $\mathrm{NaOMe} / \mathrm{MeOD}$

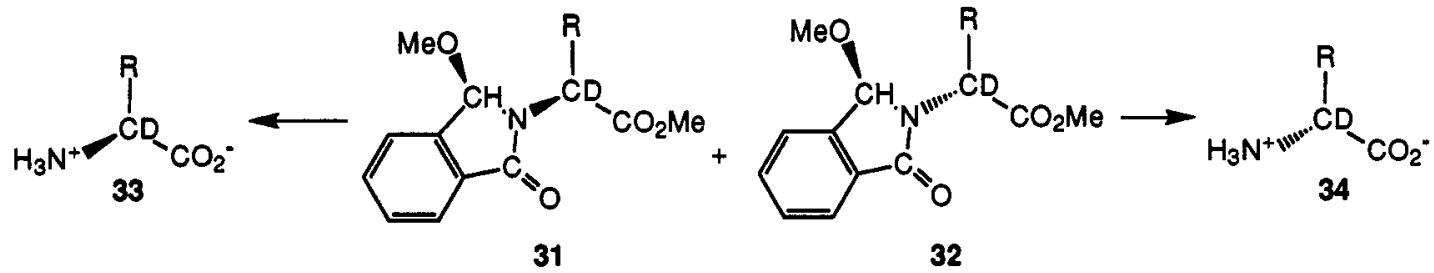

Using sodium methoxide in deuteriated methanol, the isomerisation of the partially reduced phthalimides 27a-c is accompanied by deuterium incorporation. Separation of the labelled products 31a-c and 32a-c, followed by hydrolysis, affords the $(S)$ - $\alpha$-deuterio amino acids 33a-c and the $(R)$-isomers 34a-c in a stereocontrolled fashion.

\section{Scheme 1}

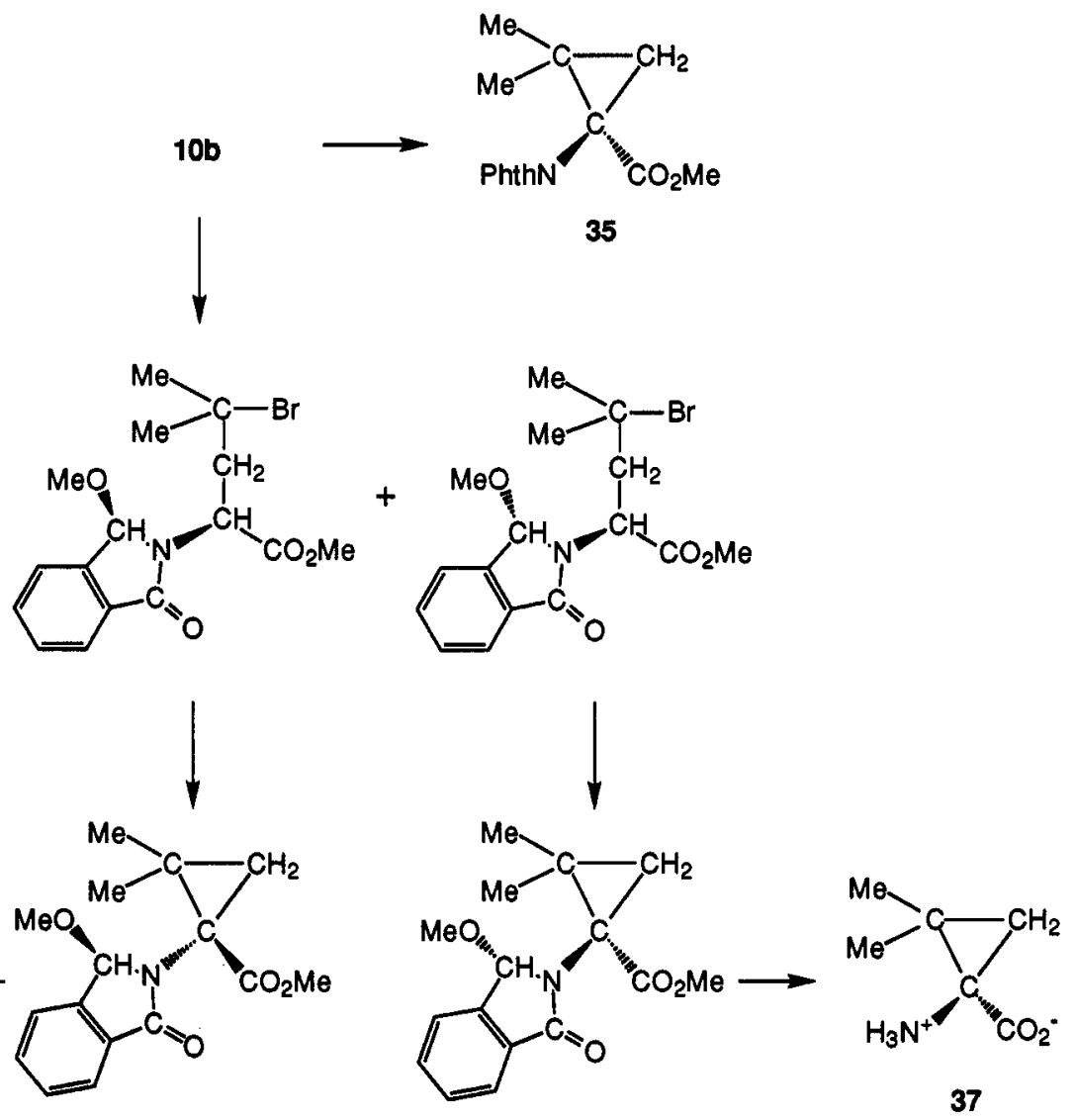

This chemistry significantly enhances the utility of the phthaloyl group in the asymmetric synthesis of amino acid derivatives, particularly when it is exploited in conjunction with the use of the phthalimide to achieve side chain functionalisation of amino acid derivatives. For example, it provides a route for the 
stereocontrolled synthesis of the methanovaline enantiomers 36 and 37 . As outlined above, halogenation of the leucine derivative 10a afforded the bromide 10b. When the bromide 10b was treated with sodium hydride, cyclisation occurred to give the methanovaline derivative 35 (ref. 16), but the reaction resulted in complete racemisation. This was avoided, however, by using the phthaloyl protecting group to remember the amino acid chirality (Scheme 1).

The author is greatly indebted to an enthusiastic group of co-workers, for their intellectual and practical contributions to this research, as well as for social interactions. Individual contributions are noted in the references.

\section{REFERENCES}

1. C. J. Easton, In Advances in Detailed Reaction Mechanisms, Vol. 1 (J. M. Coxon, ed.), pp 83-126. JAI Press, Greenwich (1991).

2. D. Elad and J. Sinnreich J. Chem. Soc., Chem. Commun. 471-472 (1965); D. Elad, M. Schwarzberg and J. Sperling J. Chem. Soc., Chem. Commun. 617-618 (1970); J. Sperling and D. Elad J. Am. Chem. Soc. 93, 3839-3840 (1971); D. Elad and J. Sperling J. Chem. Soc., Chem. Commun. 655-656 (1968); D. Elad and J. Sperling J. Chem. Soc. (C) 1579-1585 (1969); J. Sperling and D. Elad J. Am. Chem. Soc. 93, 967-971 (1971); M. Schwarzberg, J. Sperling and D. Elad J. Am. Chem. Soc. 95, 6418-6426 (1973); D. Elad and J. Sperling J. Chem. Soc., Chem. Commun. 234 (1969); P. Wheelan, W. M. Kirsch and T. H. Koch J. Org. Chem. 54, 4360-4364 (1989).

3. C. J. Easton and M. P. Hay J. Chem. Soc., Chem. Commun. 55-57 (1986); V. A. Burgess, C. J. Easton and M. P. Hay J. Am. Chem. Soc. 111, 1047-1052 (1989).

4. C. J. Easton, I. M. Scharfbillig and E. W. Tan Tetrahedron Lett. 29, 1565-1568 (1988).

5. J. E. Baldwin, R. M. Adlington, C. Lowe, I. A. O'Neil, G. L. Sanders, C. J. Schofield, and J. B. Sweeney, J. Chem. Soc., Chem. Commun. 1030-1031 (1988).

6. C. J. Easton and I. M. Scharfbillig J. Org. Chem. 55, 384-386 (1990).

7. V. A. Burgess and C. J. Easton Aust. J. Chem. 41, 1063-1070 (1988); C. J. Easton, P. D. Roselt and E. R. T. Tiekink Tetrahedron 51, 7809-7822 (1995).

8. T. W. Badran, C. J. Easton, E. Horn, K. Kociuba, B. L. May, D. M. Schliebs and E. R. T. Tiekink Tetrahedron: Asymmetry 4, 197-200 (1993).

9. U. Schöllkopf, H.-J. Neubauer and M. Hauptreif Angew. Chem., Int. Ed. Eng. 24, 1066-1067 (1985); U. Schöllkopf, S. Grïttner, R. Anderskewitz, E. Egert and M. Dyrbusch Angew. Chem., Int. Ed. Eng. 26, 683-684 (1987).

10. C. J. Easton, E. W. Tan and M. P. Hay J. Chem. Soc., Chem. Commun. 385-386 (1989); C. J. Easton, C. A. Hutton, G. Rositano and E. W. Tan J. Org. Chem. 56, 5614-5618 (1991).

11. C. J. Easton, C. A. Hutton, P. D. Roselt and E. R. T. Tiekink Aust. J. Chem, 44, 687-694 (1991).

12. C. J. Easton and C. A. Hutton J. Chem. Soc., Perkin Trans. I 3545-3548 (1994).

13. C. J. Easton, C. A. Hutton, E. W. Tan and E. R. T. Tiekink Tetrahedron Lett. 31, 7059-7062 (1990); C. J. Easton, C. A. Hutton, P. D. Roselt and E. R. T. Tiekink Tetrahedron 50, 7327-7340 (1994).

14. C. J. Easton, C. A. Hutton, M. C. Merrett and E. R. T. Tiekink Tetrahedron 52, 7025-7036 (1996).

15. N. L. Fryer and C. J. Easton, unpublished observations.

16. C. J. Easton, E. W. Tan and C. M. Ward Aust. J. Chem. 45, 395-402 (1992). 